\title{
Epidemiological characteristics and predictors of late presentation of HIV infection in Barcelona (Spain) during the period 2001-2009
}

\author{
Patricia Garcia de Olalla ${ }^{1,2^{*}}$, Christian Manzardo ${ }^{3}$, Maria A Sambeat ${ }^{4}$, Inma Ocaña ${ }^{5}$, Hernando Knobel ${ }^{6}$, \\ Victoria Humet ${ }^{7}$, Pere Domingo ${ }^{4}$, Esteve Ribera ${ }^{5}$, Ana Guelar ${ }^{6}$, Andres Marco $^{7}$, Maria J Belza ${ }^{2,8}$, Josep M Miró ${ }^{3}$, \\ Joan A Caylà ${ }^{1,2}$ and for the HIV Surveillance Group
}

\begin{abstract}
Background: Early diagnosis of HIV infection can prevent morbidity and mortality as well as reduce HIV transmission. The aim of the present study was to assess prevalence, describe trends and identify factors associated with late presentation of HIV infection in Barcelona (Spain) during the period 2001-09.

Methods: Demographic and epidemiological characteristics of cases reported to the Barcelona HIV surveillance system were analysed. Late presentation was defined for individuals with a CD4 count below 350 cells/ml upon HIV diagnosis or diagnosis of AIDS within 3 months of HIV diagnosis. Multivariate logistic regression were used to identify predictors of late presentation.

Results: Of the 2,938 newly diagnosed HIV-infected individuals, 2,507 (85,3\%) had either a CD4 cell count or an AIDS diagnosis available. A total of 1,139 (55.6\%) of the 2,507 studied cases over these nine years were late presenters varying from $48 \%$ among men who have sex with men to $70 \%$ among heterosexual men. The proportion of late presentation was $62.7 \%$ in $2001-2003,51.9 \%$ in $2004-2005,52.6 \%$ in $2006-2007$ and $52.1 \%$ in 2008-2009. A decrease over time only was observed between 2001-2003 and 2004-2005 ( $p=0.001$ ) but remained constant thereafter $(p=0.9)$. Independent risk factors for late presentation were older age at diagnosis $(p<$ $0.0001)$, use of injected drugs by men ( $p<0.0001)$, being a heterosexual men $(p<0.0001)$, and being born in South America $(p<0.0001)$ or sub-Saharan Africa $(p=0.002)$.

Conclusion: Late presentation of HIV is still too frequent in all transmission groups in spite of a strong commitment with HIV prevention in our city. It is necessary to develop interventions that increase HIV testing and facilitate earlier entry into HIV care.
\end{abstract}

Keywords: HIV infection, Late presentation, Epidemiology, Predictors, Barcelona, Spain

\section{Introduction}

In the European Union it is estimated that $15-38 \%$ of cases of HIV infection are diagnosed late [1] and 30\% of infected individuals are not aware of their serological status, with proportions that vary between $12 \%$ and $20 \%$ in Sweden to more than 50\% in Poland [2]. In Spain $56.3 \%$ of new diagnoses of HIV infection between 2003 and 2007 required treatment $(\mathrm{CD} 4<350$ cells/ $\mu \mathrm{l})$ at the

\footnotetext{
* Correspondence: polalla@aspb.cat

'Epidemiology Service. Agencia de Salut Pública de Barcelona, Barcelona, Spain

Full list of author information is available at the end of the article
}

time of diagnosis and $30.2 \%$ of these presented severe immunosuppression $(\mathrm{CD} 4<200$ cells/ $\mu \mathrm{l})$ [3].

Reducing the time elapsed between infection and the initiation of antiretroviral therapy (ART) is important to decrease progression of the infection and to facilitate immunological recovery. Therefore, early identification of infected individuals has been a priority of most AIDS prevention and control programs since the beginning of AIDS epidemic [4-6].

Delays in HIV care have serious public health implications because opportunities to prevent further transmission through effective ART are lost $[7,8]$, and because

\section{Ciomed Central}


initiating treatment for HIV infection at an advanced stage leads to poorer treatment outcomes than with early treatment $[9,10]$. Also, some studies have shown that after HIV infection diagnosis, most infected individuals remain sexually active, although most use safer practices, thereby limiting infection spread [11-13]. Late diagnosis of HIV also has economic implications for health services and society [14-16].

In Spain, all citizens enjoy universal free access to health services and ART is available for all patients. Delayed diagnosis and access to ART is essentially a public health problem and a loss of opportunity to limit the progression of disease and reduce the transmission of infection. For this reason, the objective of the present study was to determine the frequency of individuals presenting for care with a CD4 count below 350 cells/ $\mu$ l or presenting with an AIDS-defining event, to evaluate trends in this proportion, and to identify factors associated with late presentation of HIV infection in Barcelona during the period 2001-09.

\section{Methods}

The city of Barcelona (1.6 million inhabitants), is located in the northern part of the east coast of Spain. In 2001, 11.89 AIDS cases and 17.47 cases of HIV infections were registered per 100,000 inhabitants. This figures decreased to 5.9 AIDS cases and 16.7 HIV infections in 2009. The Barcelona AIDS Surveillance System, which has been active since 1987, is an active system that collects data provided by doctors, hospital discharges, the tuberculosis (TB) register, and mortality databases regarding patients diagnosed with AIDS. The voluntary HIV Surveillance System, which has been active since 2001, collects information about new diagnoses of HIV infection in individuals older than 13 years tested in public or private facilities. All AIDS cases were collected through Barcelona AIDS Surveillance, and all HIV cases from the voluntary HIV Surveillance system.

Clinicians complete a standard data collection form and use a unique patient identifier code [17].

In this study, we considered all new diagnoses of HIV infection or of AIDS within 3 months of a positive HIV test among individuals older than 13 years who were resident in Barcelona during the period 2001-09. These cases of AIDS and HIV infection met the relevant criteria of the European Centre for AIDS/HIV Epidemiological Surveillance[18].

We analysed demographic data (sex, date and country of birth, year of arrival in Spain), HIV exposure category (injecting drug users [IDU], sex between men [MSM], heterosexuals $[\mathrm{HT}])$, calendar period of HIV diagnosis (subdivided into 4 periods: 2001-03, 2004-05, 2006-07 and 2008-09), clinical data (AIDS, absolute CD4+ [CD4]).
According to the new European definition[19], late presenters (LP) was defined for persons presenting for care with a CD4 count below 350 cells/ $\mu$ l or presenting with an AIDS-defining event at the time of HIV diagnosis or within 3 months of the HIV-positive test, regardless of the CD4 cell count. Other patients were classified as non-late presenters.

\section{Statistical analyses}

A descriptive analysis of the epidemiological characteristics of cases of HIV infection defined as late presenters was carried out.

For categorical and continuous variables, we compared the count (proportion) and median (interquartile range -IQR-), respectively, of late presenters to non late presenters. Categorical variables were compared using $\chi^{2}$ test. For each comparison, the univariate odds ratio (OR), 95\% confidence interval (CI) and p-value for statistical significance were computed. Continuous variables were compared using the Mann-Whitney U test or the Kruskal-Wallis test. Trends in LP over time were analysed using the $\chi^{2}$ test for trend in proportions. Multivariate logistic regression was used to identify predictors of late presentation. A p-value of $<0.05$ was considered to be statistically significant. Statistical analyses were performed using SPSS for Windows (Version 18.0; SPSS, Chicago, IL).

All data were collected by the HIV/AIDS Registry of Barcelona City and were handled in a strictly confidential manner according to the requirements of Spanish data protection Law[20].

\section{Results}

During the study period, 2,938 new cases of HIV infection were detected, of which 2,268 (76.2\%) were detected in hospital and $670(22.8 \%)$ in non-hospital settings. The majority of cases were male (83.3\%), with a median age of 35 years, MSM (51.8\%) and 19.9\% presented with AIDS. The most common AIDS-defining conditions were TB (26.2\%), Pneumocystis jirovecii pneumonia (24.3\%) and Kaposi Sarcoma (10.3\%). In 90\% of cases the AIDS diagnosis was made within 30-days of HIV infection. We observed that the proportion of IDU among males decreased during the study period ( $\mathrm{p}<$ 0.0001 ), whereas the proportion of MSM increased from $40.2 \%$ in $2001-03$ to $61.9 \%$ in $2008-09$ ( $<<0.0001$ ). However, no significant trend was observed in IDU and HT women ( $\mathrm{p}=0.1$ y $\mathrm{p}=0.2$, respectively) (Table 1$)$. $55 \%$ of cases were born in Spain. The proportion of migrants increased from $22.6 \%$ in $2001-03$ to $45.8 \%$ in 2008-09 ( $<<0.0001$ ), of which $37.8 \%$ had been resident in Spain for less than 1 year, $38.8 \%$ between 2 and 5 years and $8.3 \%$ more than 10 years. 
Table 1 Characteristics of newly diagnosed HIV-infected patients in Barcelona (Spain), 2001-2009

\begin{tabular}{|c|c|c|c|c|c|}
\hline Characteristics & $\begin{array}{c}2001-2003 ; n=956 \\
(100 \%)\end{array}$ & $\begin{array}{c}2004-2005 ; n=630 \\
(100 \%)\end{array}$ & $\begin{array}{c}2006-2007 ; n=691 \\
(100 \%)\end{array}$ & $\begin{array}{c}2008-2009 ; n=661 \\
(100 \%)\end{array}$ & $\begin{array}{c}\text { Total; } \mathrm{N}=2938 \\
(100 \%)\end{array}$ \\
\hline \multicolumn{6}{|l|}{ Sex } \\
\hline Male & $768(80.3)$ & $502(79.7)$ & $599(86.7)$ & $581(87.9)$ & $2450(83.4)$ \\
\hline Female & $188(19.3)$ & $128(20.3)$ & $92(13.3)$ & $80(12.1)$ & $488(16.6)$ \\
\hline \multicolumn{6}{|l|}{ Age at HIV diagnosis* } \\
\hline All & $35.1(29.8-42.9)$ & $34.7(28.9-41.7)$ & $35.5(29.9-43.1)$ & $34.3(29.2-41.1)$ & $35.0(29.4-42.2)$ \\
\hline Male & $35.2(29.8-42.8)$ & $34.8(29.3-41.6)$ & $35.5(29.8-42.7)$ & $34.2(29.0-40.8)$ & $35.1(29.5-35.1)$ \\
\hline Female & $34.5(29.8-42.9)$ & $36.7(27.4-42.1)$ & $35.9(30.0-44.9)$ & $35.3(29.3-44.8)$ & $34.5(29.3-43.4)$ \\
\hline \multicolumn{6}{|l|}{ Region of birth } \\
\hline Spain & $551(57.6)$ & $353(56.0)$ & $368(53.3)$ & $344(52.0)$ & $1616(55.0)$ \\
\hline $\begin{array}{l}\text { Western Europe \& North } \\
\text { America }\end{array}$ & $53(5.5)$ & $30(4.8)$ & $53(7.7)$ & $54(8.2)$ & $190(6.5)$ \\
\hline Latin America \& Caribbean & $147(15.4)$ & $133(21.1)$ & $191(27.6)$ & $178(26.9)$ & $649(22.1)$ \\
\hline Middle East \& North Africa & $22(2.3)$ & $7(1.1)$ & $12(1.7)$ & $9(1.4)$ & $50(1.7)$ \\
\hline Sub-Saharan Africa & $30(3.1)$ & $33(5.2)$ & $20(2.9)$ & $20(3.0)$ & $103(3.5)$ \\
\hline Eastern Europe & $14(1.5)$ & $12(1.9)$ & $20(2.9)$ & $36(5.4)$ & $82(2.8)$ \\
\hline Asia & $6(0.6)$ & $6(1.0)$ & $1(0.1)$ & $6(0.9)$ & $19(0.6)$ \\
\hline unknown & $133(13.9)$ & $56(8.9)$ & $26(3.8)$ & $14(2.1)$ & $229(7.8)$ \\
\hline \multicolumn{6}{|l|}{$\begin{array}{l}\text { Exposure category by } \\
\text { sex }^{* *}\end{array}$} \\
\hline IDU men & $181(18.9)$ & $65(10.3)$ & $52(7.5)$ & $29(4.4)$ & $327(11.1)$ \\
\hline MSM & $384(40.2)$ & $320(50.8)$ & $410(59.3)$ & $409(61.9)$ & $1523(51.8)$ \\
\hline HT men & 149 (15.6) & $85(13.5)$ & $93(13.5)$ & $87(13.2)$ & $414(14.1)$ \\
\hline IDU women & $48(5.0)$ & $22(3.5)$ & $10(1.4)$ & $12(1.8)$ & $92(3.1)$ \\
\hline HT women & $129(13.5)$ & $102(16.2)$ & $74(10.7)$ & $54(8.2)$ & $359(12.2)$ \\
\hline unknown & $65(6.8)$ & $36(5.7)$ & $52(7.5)$ & $70(10.6)$ & $223(7.6)$ \\
\hline \multicolumn{6}{|l|}{ CD4 cell count and AIDS } \\
\hline AIDS & $241(25.2)$ & $105(16.7)$ & $138(20.0)$ & $100(15.1)$ & $584(19.9)$ \\
\hline$<200$ & $141(14.7)$ & $78(12.4)$ & $81(11.7)$ & $74(11.2)$ & $374(12.7)$ \\
\hline $200-349$ & $123(12.9)$ & $96(15,2)$ & $100(14,5)$ & $116(17.5)$ & $435(14.8)$ \\
\hline $350-499$ & $111(11,6)$ & $92(14.6)$ & $117(16.9)$ & $108(16.3)$ & $428(14.6)$ \\
\hline 500 and more & $189(19.8)$ & $167(26.5)$ & $171(24.7)$ & $159(24.1)$ & $686(23.3)$ \\
\hline unknown (\%) & $151(15.8)$ & $92(14.6)$ & $84(12.2)$ & $104(15.7)$ & $431(14.7)$ \\
\hline
\end{tabular}

*Median (interquartile range). **IDU: injection drug use; MSM: men who have sex with men; HT: heterosexual contact.

Either a CD4 cell count or an AIDS diagnosis were available for $85.3 \%(2,507)$ of the 2,938 newly diagnosed HIV-infected individuals. Patients whose CD4 cell count was not available differed from those for whom CD4 count was available in the frequency of IDU $(26.0 \%$ vs $12.9 \%, \mathrm{p}<0.001)$ and in the median age (34.43 years $v s$ 37.39 years, $\mathrm{p}<0.001)$.

The proportion of patients who were LP was $55.6 \%$ (1,393 persons) and $38.5 \%$ had advanced HIV infection (15.2\% presenting with CD $4<200 \mathrm{cell} / / \mu \mathrm{l}$ and $23.3 \%$ with AIDS regardless of the CD4 cell count). A decrease of LP over time only was observed from $62.7 \%$ in 2001 03 to $51,9 \%$ in $2004-05$ ( $\mathrm{p}=0.001$ ), but remained constant thereafter $(\mathrm{p}=0.9)$. Figure 1 shows the proportion of individual by CD4 count/AIDS at the time of HIV diagnosis according to category of exposure: $48 \%$ of
MSM had < $350 \mathrm{CD} 4 / \mu \mathrm{l}$, whereas among IDU men and HT men this percentage was $66 \%$ and $70 \%$, respectively.

LP was slightly, but not significantly, more frequent among women than among men (58.5\% vs 55.0\%). However, differences were observed according to age, region of birth, category of exposure and period of diagnosis (Table 2). The logistic regression model showed that risk of LP was associated with age: for each increment of 5 years, risk of being a late presenter increased by $38 \%$; with region of birth: LP was significantly more common among individuals born in Latin America and Caribbean (OR:1.48; CI: 1.20-1.83) and Sub-Saharan Africa (OR:2.43; CI: 1.14-4.17) than among individuals born in Spain; with category of exposure and sex: IDU and HT men showed an OR for risk of being LP of 2.12 (1.57-2.87) and 1.79 (1.38-2.34), respectively, compared 


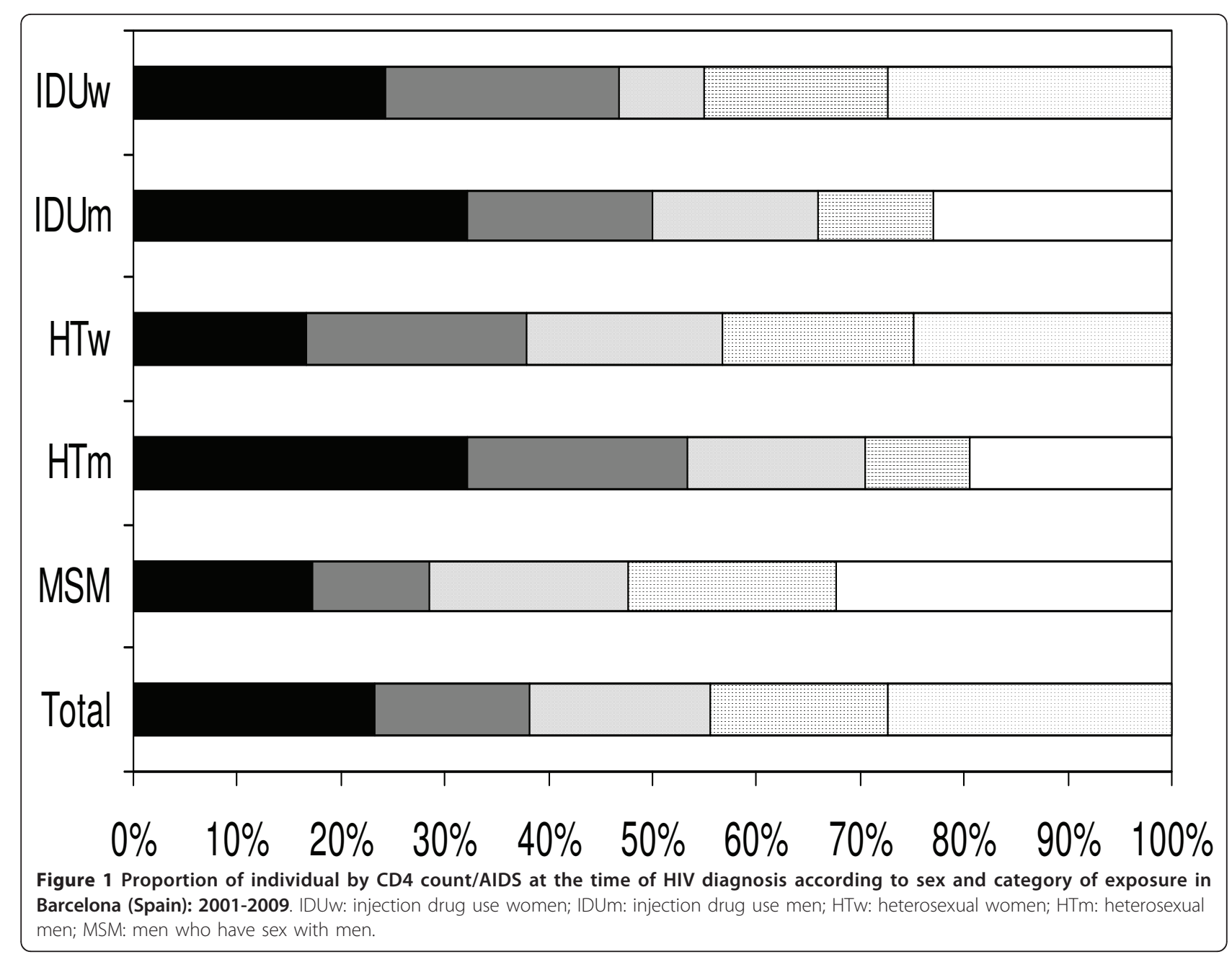

to MSM. A decrease in the risk of being LP was observed in the last three periods compared to the period 2001-03 (Table 2).

In $650(33.8 \%)$ cases of the 1,923 new diagnoses of HIV infection with CD4 count data and without AIDS the median time elapsed between the diagnosis of infection and the first determination of CD4 was 56 days (15-129), with differences according to category of exposure. Among IDU, the median time interval was 162 days (40-495), while for other exposures it was 54 days $(14-115)(\mathrm{p}=0,002)$.

\section{Discussion}

This study shows that a high proportion of individuals (55.6\%) meet the criteria of the new European definition of LP (CD4 < 350 cells/ $\mu$ l or AIDS). Although it is difficult to obtain data on LP in large cities, these figures do not differ greatly from those observed at national or regional level, even in areas where the prevention of HIV infection is a priority $[1,3,21,22]$. Thus, $50 \%$ of new diagnoses of HIV infection occur when the subject needs treatment [23]. If we take into account the new ARV treatment recommendations, which indicate that treatment should be started in asymptomatic patients with CD 4500 cells $/ \mu$ l, this proportion reaches $70 \%$ [24-26]. These high proportions of patients with "carestage" HIV infection at their initial clinic visit suggests that barriers to HIV care are also considerable in developed countries. The negative impact of LP is a likely increase in morbidity and mortality $[27,28]$, more potential transmission at the community level [13] and further treatment costs [14-16].

The proportion of LP decreased only between 2001-03 and 2004-05, as has been observed in other studies $[3,29]$, it continues to be high in all groups. LP is associated with age and affects all subpopulations, although its distribution is not homogeneous $[3,30]^{\cdot}$ The limited perception of risk [31] compounds the fact that tests tend to be offered less frequently to older individuals. Heterosexual individuals over 50 years are not the target of most prevention campaigns [32]. In general, individuals born outside Spain presented greater risk of LP 
Table 2 Characteristics and factors associated with late presentation for newly HIV diagnosis in Barcelona (Spain), 2001-2009

\begin{tabular}{|c|c|c|c|c|c|c|}
\hline Characteristics & Total $\mathrm{N}=2507$ & Late presenters (\%) & Unadjusted OR (CI) & $\mathrm{p}$ value & Adjusted OR (Cl) & $\mathrm{p}$ value \\
\hline \multicolumn{7}{|l|}{ Sex } \\
\hline Male & 2097 & $1153(55.0)$ & 1 & 0.18 & & \\
\hline Female & 410 & $240(58.5)$ & $1.16(0.93-1.44)$ & & & \\
\hline \multicolumn{7}{|l|}{ Age at HIV diagnosis* } \\
\hline All & $35.4(29.6-42.8)$ & $37.9(31.5-46.2)$ & & 0.0001 & $1.38(1.27-1.40)$ & $<0.0001$ \\
\hline Male & $35.4(29.7-42.5)$ & $38.0(31.8-45.8)$ & & & & \\
\hline Female & $35.3(29.4-44.4)$ & $37.7(30.6-47.2)$ & & & & \\
\hline \multicolumn{7}{|l|}{ Age (per a 5 yrs increase) } \\
\hline \multicolumn{7}{|l|}{ Region of birth } \\
\hline Spain & 1460 & $826(56.6)$ & 1 & 0.002 & 1 & 0.279 \\
\hline Western Europe \& North America & 166 & $73(44.0)$ & $0.60(0.43-0.84)$ & 0.2 & $0.83(0.59-1.16)$ & $<0.0001$ \\
\hline Latin America \& Caribbean & 570 & $315(55.3)$ & $0.95(0.78-1.16)$ & 0.8 & $1.48(1.20-1.83)$ & 0.838 \\
\hline Middle East \& North Africa & 44 & $26(59.1)$ & $1.11(0.58-2.13)$ & 0.02 & $1.07(0.56-2.03)$ & 0.002 \\
\hline Sub-Saharan Africa & 74 & $52(70.3)$ & $1.81(1.08-3.12)$ & 0.9 & $2.43(1.14-4.17)$ & 0.274 \\
\hline Eastern Europe & 64 & $36(56.3)$ & $0.99(0.58-1.68)$ & 0.2 & $1.35(0.79-2.31)$ & 0.219 \\
\hline Asia & 18 & $13(72.2)$ & $2.00(0.66-6.44)$ & 0.05 & $1.96(0.67-5.74)$ & 0.107 \\
\hline unknown & 111 & $52(46.8)$ & $0.68(0.45-1.01)$ & & $0.71(0.47-1.07)$ & \\
\hline \multicolumn{7}{|l|}{ Exposure category** } \\
\hline MSM & 1333 & $636(47.7)$ & 1 & $<0.001$ & 1 & $<0.0001$ \\
\hline IDU men & 252 & $166(65.9)$ & $2.12(1.58-2.83)$ & $<0.001$ & $2.12(1.57-2.87)$ & $<0.0001$ \\
\hline $\mathrm{HT}$ men & 382 & $269(70.4)$ & $2.61(2.03-3.36)$ & 0.9 & $1.79(1.38-2.34)$ & 0.340 \\
\hline IDU women & 62 & $34(54.8)$ & $1.33(0.78-2.29)$ & 0.004 & $1.29(0.76-2.20)$ & 0.279 \\
\hline HT women & 319 & $181(56.7)$ & $1.44(1.12-1.85)$ & $<0.001$ & $1.16(0.88-1.51)$ & 0.009 \\
\hline unknown & 159 & $107(67.3)$ & $2.26(1.57-3.24)$ & & $1.63(1.13-2.37)$ & \\
\hline \multicolumn{7}{|l|}{ Year of diagnosis } \\
\hline $2001-2003$ & 805 & $505(62.7)$ & 1 & $<0.001$ & 1 & 0.001 \\
\hline 2004-2005 & 538 & $279(51.2)$ & $0.64(0.51-0.80)$ & $<0.001$ & $0.67(0.53-0.85)$ & 0.001 \\
\hline $2006-2007$ & 607 & $319(52.6)$ & $0.66(0.53-0.82)$ & $<0.001$ & $0.67(0.53-0.85)$ & 0.001 \\
\hline $2008-2009$ & 557 & $290(52.1)$ & $0.65(0.52-0.81)$ & & $0.71(0.56-0.90)$ & \\
\hline
\end{tabular}

*Median (interquartile range). **IDU: injection drug use; MSM:men who have sex with men; HT:heterosexual contact.

than Spanish nationals, most notably individuals born in Latin America and Sub-Saharan Africa, as observed in other studies $[3,10]$. In a study carried out in Italy, a greater proportion of LP was also observed in the immigrant population [29].

In relation to sex and the mechanism of transmission, it was observed that IDU men and HT men presented a higher frequency of LP compared to MSM. This higher proportion of delayed diagnoses among heterosexuals compared to cases of homosexual transmission has been highlighted in various studies [33-35]. A greater probability of delayed diagnosis has been observed in Italy, but only in drug addicts that remained isolated from social and health services [36]. However in our study, comparing the MSM group with IDU women or HT women this difference disappears. This may be due to women's higher perception of risk, their greater likelihood of attending health services [37] and the probability that they will be offered the test during pregnancy or birth, as a result of which they will be diagnosed earlier than HT or IDU men.

Some results of this study suggest that the delay among IDU is more a delay in beginning treatment than in diagnosis of the infection, since they are often diagnosed in drug rehabilitation centres or in prison. In this sense, the overrepresentation of IDU without lymphocyte count data would indicate that the diagnostic test is carried out on these individuals, but many are lost to follow-up. Moreover, the median time elapsed between the diagnosis of infection and the determination of CD4 was notably higher among the IDU (162 days) compared to other categories of exposure (54 days), which would indicate that the delay in this group was more likely due to a delay in beginning treatment than delayed diagnosis, as observed in other studies [38,39]. Consequently, public health strategies aimed at ensuring access to health resources are a priority for diminishing LP in this group. An early diagnosis, especially in this group does 
not necessarily require that the patient be undergoing follow-up or treatment $[40,41]$. However, reinforcing the strategies that increase the availability of the test should be directed in the first place at those individuals likely to be at high risk for HIV infection based on the presence of indicator situations or events where the estimated prevalence of HIV-1 infection is above $1 \%$, and at the most vulnerable groups [42-44].

Among the limitations of this study, we highlight the number of cases without data on lymphocyte count (14.7\%) with a different distribution in the case of the IDU, which may lead to underestimation of the results for this group in our study. Another limitation could be the under-reporting of HIV infection due to the fact that this was voluntary. This underreporting is estimated around 15\%-20\% (unpublished data).

\section{Conclusion}

In conclusion, late presentation of HIV is common in spite of a strong commitment to universal access to HIV infection prevention, diagnosis and treatment in our city. This study reveals a need to develop interventions that increase HIV testing and facilitate earlier entry into care, such as routine screening in healthcare and non-clinical settings for patients at risk for HIV (e. g. have unprotected sex with many sex partners, have a sexually transmitted infection, have a diagnosis of tuberculosis, use illegal injected drugs, pregnancy). An accurate sexual history and other risk factors, together with knowledge of country of birth, can identify most individuals who should be offered an HIV test and a link to care.

\begin{abstract}
Abbreviations
ART: antiretroviral therapy; Cl: confidence interval; HIV: human immunodeficiency virus; $H T$ : heterosexual relationships; HTw: heterosexual women; HTm: heterosexual men; IDU: injecting drug users; IDUw: injection drug use women; IDUm: injection drug use men; late presenters (LP): persons presenting for care with a CD4 count below 350 cells $/ \mathrm{ml}$ or presenting with an AIDS-defining event at the time of HIV diagnosis or within 3 months of the HIV-positive test, regardless of the CD4 cell count; MSM: sex between men; OR: odds ratio; TB: tuberculosis.
\end{abstract}

\section{Acknowledgements}

We would like to thank to Dr. Joan R Villalbí, epidemiologist of Agència de Salut Pública de Barcelona, for their valuable comments.

Members of the HIV Surveillance Group: Roser Clos, Pilar Gorrindo

(Agència de Salut Pública de Barcelona); Mercè Gurguí, Maria G Mateo, Maria M Gutiérrez, Josep Cadafalch (Hospital de la Santa Creu i Sant Pau. Universitat Autònoma de Barcelona); Vicenç Falcó (Hospital Vall de Hebron. Universitat Autònoma de Barcelona):Teresa Carbonell (Hospital Universitari del Mar); José I Pérez, Felipe García, José L Blanco, Esteban Martínez, Josep Mallolas, Josep M Gatell (Hospital Clinic-IDIBAPS. University of Barcelona).

\section{Author details}

'Epidemiology Service. Agencia de Salut Pública de Barcelona, Barcelona, Spain. ${ }^{2}$ Consorcio de Investigación Biomédica en Red de Epidemiología y Salud Pública (CIBERESP. ${ }^{3}$ Hospital Clinic-IDIBAPS. University of Barcelona, Barcelona, Spain. ${ }^{4}$ Infeccious Diseases Unit, Hospital de la Santa Creu i Sant Pau. Universitat Autònoma de Barcelona, Barcelona, Spain. Infectious
Diseases, Hospital Vall de Hebron. Universitat Autònoma de Barcelona, Barcelona, Spain. 'Internal Medicine-Infectious Diseases, Hospital del Mar, Barcelona, Spain. ${ }^{7}$ Direcció General de Serveis Penitenciaris i de Rehabilitació. Departament de Justícia. Barcelona, Spain. ${ }^{8}$ Escuela Nacional de Sanidad, Instituto de Salud Carlos III, Madrid, Spain.

\section{Authors' contributions}

PGdeO, JAC designed the study, interpreted the data, and drafted the manuscript. PGdeO and MJB analysed the data. CM, MAS, IO, HK, VH, PD, ER, AG, AM, JMM and the HIV Surveillance Group collected data and notified the cases, and participated in writing and revised critically the manuscript. All authors have reviewed and approved the final manuscript.

\section{Competing interests}

The authors declare that they have not competing interests.

Received: 18 April 2011 Accepted: 6 July 2011 Published: 6 July 2011

\section{References}

1. Adler A, Mounier-Jack S, Coker RJ: Late diagnosis of HIV in Europe: definitional and public health challenges. AIDS Care 2009, 21:284-293.

2. Hamers FF, Phillips AN: Diagnosed and undiagnosed HIV-infected populations in Europe. HIV Med 2008, 9(Suppl 2):6-12.

3. Oliva J, Galindo S, Vives N, Arrillaga A, Izquierdo A, Nicolau A, Castilla J, Lezaun ME, Alvarez M, Rivas A, Díez M: Delayed diagnosis of HIV infection in Spain. Enferm Infecc Microbiol Clin 2010, 28:583-589.

4. World Health Organization: Report of the Meeting on Criteria for HIV Screening Programes [WHO/SPA/GLO/87.2]. Geneva:WHO; 1987 [http:// whqlibdoc.who.int/hq/1987/WHO_SPA_GLO_87.2_spa.pdf], Accessed January 2011.

5. Branson BM, Handsfield HH, Lampe MA, Janssen RS, Taylor AW, Lyss SB, Clark JE: Centers for Disease Control and Prevention (CDC). Revised recommendations for HIV testing of adults, adolescents, and pregnant women in health-care settings. MMWR Recomm Rep 2006, 55(RR-14):1-17.

6. Secretaría del Plan Nacional sobre el Sida. Infección por VIH y SIDA: Plan Multisectorial 2008-2012. Ministerio de Sanidad y Consumo. Madrid 2008 [http://www.msps.es/ciudadanos/enfLesiones/enfTransmisibles/sida/docs/ PMS200812.pdf], Accessed January 2011.

7. Attia S, Egger M, Muller M, Zwahlen M, Low N: Sexual transmission of HIV according to viral load and antiretroviral therapy: systematic review and meta-analysis. AIDS 2009, 23:1397-1404.

8. Marks G, Crepaz N, Senterfitt JW, Janssen RS: Meta-analysis of high-risk sexual behavior in persons aware and unaware they are infected with HIV in the United States: implications for HIV prevention programs. J Acquir Immune Defic Syndr 2005, 39:446-453.

9. Palella FJ Jr, Delaney KM, Moorman AC, Loveless MO, Fuhrer J, Satten GA Aschman DJ, Holmberg SD: Declining morbidity and mortality among patients with advanced human immunodeficiency virus infection. HIV Outpatient Study Investigators. N Engl J Med 1998, 338:853-860.

10. Sobrino-Vegas P, García-San Miguel L, Caro-Murillo AM, Miró JM, Viciana P, Tural C, Saumoy M, Santos I, Sola J, del Amo J, Moreno S, CoRIS: Delayed diagnosis of HIV infection in a multicenter cohort: prevalence, risk factors, response to HAART and impact on mortality. Curr HIV Res 2009, 7:224-230

11. Weinhardt LS, Carey MP, Johnson BT: Effect of HIV counseling and testing on sexual behavior: a meta-analytic review of published research, 19851997. Am J Pub Health 1999, 89:1397-1410.

12. Johnson WD, Diaz RM, Flanders WD, Goodman M, Hill AN, Holtgrave D, Malow R, McClellan WM: Behavioral interventions to reduce risk for sexual transmission of HIV among men who have sex with men. Cochrane Database Syst Rev 2008, 3:CD001230.

13. Marks G, Crepaz N, Janssen RS: Estimating sexual transmission of HIV from persons aware and unaware that they are infected with the virus in the USA. AIDS 2006, 20:1447-1450.

14. Fleishman JA, Yehia BR, Moore RD, Gebo KA, HIV Research Network: The economic burden of late entry into medical care for patients with HIV infection. Med Care 2010, 48:1071-1079[http://www.ncbi.nlm.nih.gov/pmc/ articles/PMC3022268/pdf/nihms-262526.pdf], Accessed February 2011.

15. Velasco M, Losa JE, Espinosa A, Sanz J, Gaspar G, Cervero M, Torres R, Condes E, Barros C, Castilla V: Economic evaluation of assistance to HIV patients in a Spanish hospital. Eur J Intern Med 2007, 18:400-404. 
16. Krentz HB, Gill J: Despite CD4 cell count rebound the higher initial costs of medical care for HIV-infected patients persist 5 years after presentation with CD4 cell counts less than $350 \mu$ l. AIDS 2010, 24:2750-2753.

17. Romaguera A, Binefa G, Casabona J, García de Olalla P, Caylà J, Camps N, Company M, Minguell S, Godoy P, Sala MR, Humet V, Alvarez J, Barrabeig I, Grupo de médicos coordinadores de VIH/sida: Reporting of newly diagnosed HIV infections in Catalonia, Barcelona, Spain. Implementation and results. Gac Sanit 2005, 19:356-362.

18. Commission decision of 28/IV/2008 amending Decision 2002/253/EC laying down case definitions for reporting communicable diseases to the Community network under Decision No 2119/98/EC of the European Parliament and of the Council. Acquired Immunodeficiency Virus (AIDS) and Human Immunodeficiency Virus (HIV) Infection [http://www.ecdc.europa.eu/ en/healthtopics/spotlight/Documents/

080428_amending_desicion_Decision_2002-253-EC_on_case\%20definitions. pdf], Accessed February 2011.

19. Antinori A, Coenen T, Costagiola D, Dedes N, Ellefson M, Gatell J, Girardi E, Johnson M, Kirk O, Lundgren J, Mocroft A, D'Arminio Monforte A, Phillips A, Raben D, Rockstroh JK, Sabin C, Sönnerborg A, De Wolf F, European Late Presenter Consensus Working Group: Late presentation of HIV infection: a consensus definition. HIV Med 2011, 12:61-64.

20. 23750 LEY ORGÁNICA 15/1999, de 13 de diciembre, de Protección de Datos de Carácter Personal. BOE núm. 298. 1999, 43088-43097[http:// www.boe.es/boe/dias/1999/12/14/pdfs/A43088-43099.pdf], Accessed February 2011

21. Caro-Murillo AM, Castilla J, Pérez-Hoyos S, Miró JM, Podzamczer D, Rubio R, Riera M, Viciana P, López Aldeguer J, Iribarren JA, de los Santos-Gil I, Gómez-Sirvent JL, Berenguer J, Gutiérrez F, Saumoy M, Segura F, Soriano V, Peña A, Pulido F, Oteo JA, Leal M, Casabona J, del Amo J, Moreno S, Grupo de trabajo de la Cohorte de la Red de Investigación en Sida (CoRIS): Spanish cohort of naïve HIV-infected patients (CoRIS): rationale, organization and initial results. Enferm Infecc Microbiol Clin 2007, 25:23-31.

22. Althoff KN, Gange SJ, Klein MB, Brooks JT, Hogg RS, Bosch RJ, Horberg MA, Saag MS, Kitahata MM, Justice AC, Gebo KA, Eron JJ, Rourke SB, Gill MJ, Rodriguez B, Sterling TR, Calzavara LM, Deeks SG, Martin JN, Rachlis AR, Napravnik S, Jacobson LP, Kirk GD, Collier AC, Benson CA, Silverberg MJ, Kushel M, Goedert JJ, McKaig RG, Van Rompaey SE, Zhang J, Moore RD: Late presentation for human immunodeficiency virus care in the United States and Canada. Clin Infect Dis 2010, 50:1512-1520.

23. When To Start Consortium, Sterne JA, May M, Costagliola D, de Wolf F, Phillips AN, Harris R, Funk MJ, Geskus RB, Gill J, Dabis F, Miró JM, Justice AC, Ledergerber B, Fätkenheuer G, Hogg RS, Monforte AD, Saag M, Smith C, Staszewski S, Egger M, Cole SR: Timing of initiation of antiretroviral therapy in AIDS-free HIV-1-infected patients: a collaborative analysis of 18 HIV cohort studies. Lancet 2009, 373:1352-1363.

24. Thompson MA, Aberg JA, Cahn P, Montaner JS, Rizzardini G, Telenti A, Gatell JM, Günthard HF, Hammer SM, Hirsch MS, Jacobsen DM, Reiss P, Richman DD, Volberding PA, Yeni P, Schooley RT: Antiretroviral treatment of adult HIV infection: 2010 recommendations of the International AIDS Society-USA panel. JAMA 2010, 304:321-333.

25. Panel de expertos de Gesida y Plan Nacional sobre el Sida: Recomendaciones de GESIDA/Plan Nacional sobre el Sida infectados por el virus de la inmunodeficiencia humana (Actualización enero 2010). Enferm Infecc Microbiol Clin 2010, 28:362-391.

26. European AIDS Clinical Society: Treatment guidelines (EACS).[http://www. europeanaidsclinicalsociety.org/images/stories/EACS-Pdf/eacseuroguidelines_fullversion.pdf], Accessed March 2011

27. Antiretroviral therapy cohort collaboration (ART-CC), Lanoy E, May M, Mocroft A, Phillip A, Justice A, Chêne G, Furrer $H$, Sterling T, Monforte AD, Force L, Gill J, Harris R, Hogg RS, Rockstroh J, Saag M, Khaykin P, de Wolf F, Sterne JA, Costagliola D: Prognosis of patients treated with CART from 36 months after initiation, according to current and previous CD4 cell count and plasma HIV-1 RNA measurements. AIDS 2009, 23:2199-2208.

28. Moore DM, Harris R, Lima V, Hogg B, May M, Yip B, Justice A, Mocroft A, Reiss P, Lampe F, Chêne G, Costagliola D, Elzi L, Mugavero MJ, Monforte AD, Sabin C, Podzamczer D, Fätkenheuer G, Staszewski S, Gill J, Sterne JA, Antiretroviral Therapy Cohort Collaboration: Effect of baseline CD4 cell counts on the clinical significance of short-term immunologic response to antiretroviral therapy in individuals with virologic suppression. J Acquir Immune Defic Syndr 2009, 52:357-363.
29. Borghi V, Girardi E, Bellelli S, Angeletti C, Mussini C, Porter K, Esposito R: Late presenters in an HIV surveillance system in Italy during the period 1992-2006. J Acquir Immune Defic Syndr 2008, 49:282-286.

30. Centers for Disease Control and Prevention (CDC): Vital signs: HIV testing and diagnosis among adults-United States, 2001-2009. MMWR Morb Mortal Wkly Rep 2010, 59:1550-1555.

31. Blanco JR, Caro AM, Pérez-Cachafeiro S, Gutiérrez F, Iribarren JA, GonzálezGarcía J, Ferrando-Martínez S, Navarro G, Moreno S: HIV Infection and Aging. AIDS Rev 2010, 12:218-230.

32. Althoff KN, Gebo KA, Gange SJ, Klein MB, Brooks JT, Hogg RS, Bosch RJ, Horberg MA, Saag MS, Kitahata MM, Eron JJ, Napravnik S, Rourke SB, Gill MJ, Rodriguez B, Sterling TR, Deeks SG, Martin JN, Jacobson LP, Kirk GD, Collier AC, Benson CA, Silverberg MJ, Goedert JJ, McKaig RG, Thorne J, Rachlis A, Moore RD, Justice AC, for the North American AIDS Cohort Collaboration on Research and Design: CD4 count at presentation for HIV care in the United States and Canada: Are those over 50 years more likely to have a delayed presentation? AIDS Res Ther 2010, 7:45[http:// www.ncbi.nlm.nih.gov/pmc/articles/PMC3022663/pdf/1742-6405-7-45.pdf], Accessed March 2011.

33. Manavi K, McMillan A, Ogilvie M, Scott G: Heterosexual men and women with HIV test positive at a later stage of infection than homo- or bisexual men. Int J STD AIDS 2004, 15:811-814.

34. Centers for Disease Control and Prevention (CDC): Late versus early testing of HIV-16 Sites, United States, 2000-2003. MMWR 2003, 52:581-586.

35. Sabin CA, Smith CJ, Gumley H, Murphy G, Lampe FC, Phillips AN, Prinz B, Youle M, Johnson MA: Late presenters in the era of highly active antiretroviral therapy: uptake of and responses to antiretroviral therapy. AIDS 2004, 18:2145-2151.

36. Castelnuovo B, Chiesa E, Rusconi S, Adorni F, Bongiovanni M, Melzi S, Cicconi P, Tordato F, Meroni L, Bini T, d'Arminio Monforte A: Declining incidence of AIDS and increasing prevalence of AIDS presenters among AIDS patients in Italy. Eur J Clin Microbiol Infect Dis 2003, 22:663-669.

37. Hibbard JH, Pope CR: Gender roles, illness orientation and use of medical services. Soc Sci Med 1983, 17:129-137.

38. Girardi E, Aloisi MS, Arici C, Pezzotti P, Serraino D, Balzano R, Vigevani G, Alberici F, Ursitti M, D'Alessandro M, d'Arminio Monforte A, Ippolito G, for the ICoNA Behavioural Epidemiology Study Group: Delayed presentation and late testing for HIV: demographic and behavioral risk factors in a multicenter study in Italy. J Acquir Immune Defic Syndr 2004, 36:951-959.

39. Ndiaye B, Salleron J, Vincent A, Bataille P, Bonnevie F, Choisy P, Cochonat K, Fontier C, Guerroumi H, Vandercam B, Melliez H, Yazdanpanah Y: Factors associated with presentation to care with advanced HIV disease in Brussels and Northern France: 1997-2007. BMC Infect Dis 2011, 11:11 [http://www.biomedcentral.com/content/pdf/1471-2334-11-11.pdf], Accessed March 2011.

40. Grigoryan A, Hall HI, Durant T, Wei X: Late HIV diagnosis and determinants of progression to AIDS or death after HIV diagnosis among injection drug users, 33 US States, 1996-2004. PLoS One 2009, 4 e4445.

41. Larson BA, Brennan A, McNamara L, Long L, Rosen S, Sanne I, Fox MP: Lost opportunities to complete CD4+ lymphocyte testing among patients who tested positive for HIV in South Africa. Bull World Health Organ 2010, 88:675-680.

42. Gatell JM, Zulaica D, del Romero J, Robledo T: Cómo promover y facilitar el diagnóstico precoz de la infección por el VIH-1. Enf Emerg 2010, 12:121-124.

43. Girardi E, Sabin CA, Monforte AD: Late diagnosis of HIV infection: epidemiological features, consequences and strategies to encourage earlier testing. J Acquir Immune Defic Syndr 2007, 46(Suppl 1):S3-S8.

44. Delpierre C, Cuzin L, Lauwers-Cances V, Marchou B, Lang T: High-Risk groups for late diagnosis of HIV infection: a need for rethinking testing policy in the general population. AIDS Patient Care STDS 2006, 20:838-847.

doi:10.1186/1742-6405-8-22

Cite this article as: de Olalla et al:: Epidemiological characteristics and predictors of late presentation of HIV infection in Barcelona (Spain) during the period 2001-2009. AlDS Research and Therapy 2011 8:22. 